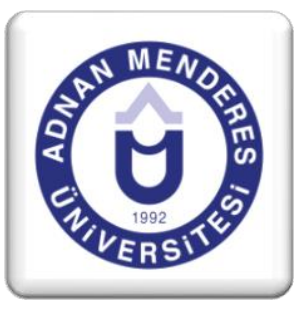

\title{
Ziya Gökalp ve Türkçülük Üzerine Bazı Değerlendirmeler
}

\author{
Mehmet Emin BARS
}

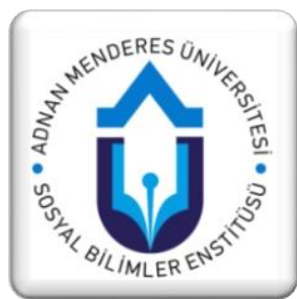

\section{ÖZET}

Ziya Gökalp, Türk folklorunu ve tarihini bir bütünlük içinde öğrenmeye çalışan bilim adamlarından biridir. Gökalp'ın yaptığg çalışmalar Türk kültürü ve Türk halk bilimi çalışmalarında önemli bir yer tutmaktadır. Onun çalışmalarının etkileri ve yöntemleri günümüze kadar ulaşmış, izinde yürüyen birçok halk bilimci yetişmiştir. Gökalp fikir dünyasını Türkçülük temeline oturtmuştur. Önceleri Osmanlıcılıktan İslamcıllığa kadar değișen görüşlerin sahibi olmuşsa da, bunların etkisi çok çabuk geçmiş ve sonunda Türkçülükte karar kılmıştır. Ziya Gökalp, Türkiye Cumhuriyeti'nin kuruluş döneminin Türkçülük düşüncesinin en önemli teorisyenlerinden biridir. $\mathrm{O}$, Türk fikir hayatında adından çokça söz ettiren bir düşünce adamıdır. Birçok eserinde Türkçülük düşüncesini işlemiştir. Gökalp'ın fikirleri Türkiye Cumhuriyeti'ne şekil ve istikamet vermiştir. Atatürk inkılaplarının temelinde Gökalp'ın düşünceleri vardır. Atatürk, Gökalp'ı fikirlerinin babası olarak görür. Gökalp tarafından teorisi ortaya atılan Türk milliyetçiliği ile daha önceki yüzyıllarda yaşanan din, mezhep ve irk ayrımlarından kaynaklanan savaşlara son verilmiştir. Türk milliyetçiliği ile kültürel birliktelik sağlanmıştır.

Anahtar Kelimeler: Ziya Gökalp, Türkçülük, vatan, halk.

\section{Some Evaluation on Ziya Gökalp and Turkism}

\begin{abstract}
Ziya Gökalp is one of the scientists who try to learn Turkish folklore and history in an integrated way. Gökalp's work has an important place in Turkish culture and Turkish folklore studies. The effects and methods of his work have reached until today, many folk scientists who have been influenced by his work have grown up. Ziya Gökalp put the world of ideas on the basis of Turkism. Gökalp first accepted ideas such as Ottomanism and Islamism. Their influence has passed very quickly and finally it has been decided in Turkism. Ziya Gokalp is one of the most important theoreticians of Turkish thought in the establishment period of the Republic of Turkey. He is an important thinker of the Turkish idea of life. He has dealt with the idea of Turkism in many of his works. Gokalp's ideas gave shape and direction to the Republic of Turkey. Atatürk's reforms are based on Gökalp's thoughts. Atatürk regards Gökalp as the father of his ideas. The Turkish nationalism, which was theorized by Gokalp, was put to an end by the wars of religious, sectarian and racial discrimination experienced in the previous centuries. Turkish nationalism is the basis of political and cultural unity.
\end{abstract}

Key Words: Ziya Gökalp, Turkism, homeland, people. 


\section{Giriş}

Millet, kendisine mahsus bir kültüre sahip olan zümredir. Ortak bir kültür etrafında birleşen topluluklar bir milleti oluşturur. Kültür dil, din ve tarih gibi önemli üç unsurun birleşmesinden meydana gelir. Bu nedenle millet; aynı dili konuşan, aynı dine iman eden ve ortak bir geçmişi olan insan topluluğudur. Bir ülkede farklı kavimlerden insanlar, ortak bir kültür etrafında birleşerek bir millet oluşturabilir.

Milliyetçilik (Ulusçuluk) bireyde genetik, fiziksel, kültürel, toplumsal ve doğal koşulların etkisi altında gelişir. Milliyetçilik, bir ulusun bireylerinde ortak olan duyguların, ülkülerin ve değerlerin toplamıdır. Bu duygu ve değerler, her zaman için bireysel çıkarların üstünde tutulur. Ulus bireysellikten önce geldiğinden dolayı, ulus için önemli ve kazançlı olan bir günde, ortak sevinç duyulur. Örneğin; ulusal bayramlarda, çeşitli alanlarda kazanılan başarılarda ortak mutluluk duyulur. Ya da ulusun genel çıkarlarına bir zarar gelmesi durumunda, aynı şekilde ortak acı paylaşılır. Sevinçli ve acılı günlerinde toplumun bireyleri dayanışma içine girerler. Büyük bir sel felaketi, deprem ve yangın, savaşlardaki yenilgiler ya da herhangi bir konudaki başarısızlık, ulus açısından önemli birinin kaybedilmesi gibi durumlarda ortak üzüntü paylaşılır. Milliyetçilik duygusu, insanlık tarihi kadar eskidir. Ancak Fransız İhtilali'nden sonra önüne geçilmez bir durum almıştır. Her ulusun kendi ulusal devletini kurma isteği, çok uluslu imparatorlukların dağılmasına neden olmuştur. Osmanlı Devleti de çok uluslu bir yapıya sahipti. Bu nedenle, onun dağılması da kaçınılmazdı. Genç Osmanlı aydınlarının bu dağılmayı görerek, ortaya attıkları vatan ve siyasal birlik kavramına dayanan "Osmanlıcılık" ile din birliğini öngören "İslamcıllk" düşüncesi aynı sonla karşı karşıya kalmıştır (Dinç, http://turkoloji.cu.edu.tr/ATATURK/arastirmalar/sait_dinc_ataturkcu_dusunce_sistemi_milli yetcilik_ilkesi.pdf.). Bir ulusun oluşumunda kültür ve tarih birliğinin ne denli önemi varsa, o ulusun güçlü bir şekilde, sonsuza kadar yaşayabilmesi için de ülkü birliğinin önemi vardır.

Tanzimat Dönemi'nde meydana gelen siyasî yenileşme hareketleri, toplumsal bir boyut kazanarak beraberinde sosyal hayata ve edebiyata da tesir eder. Tanzimat dönemi aydınları toplumu yeni bir paradigma ile okumaya çalışır. Tanzimat aydınları, Divan edebiyatının Arap ve Fars etkisiyle şekillenen dilinin yerine halkın günlük konuşma dilini getirmeye çalışırlar. Ancak bu dönemde, sanatsal değer taşıyan edebî ürünler hala seçkin kimseler dışında kalan geniş kitleler için icra edilememiştir. Örneğin Servet-i Fünun ve Fecr-i Ati toplulukları, sanatın estetik dilinin yalın olamayacağını ileri sürerler. Fakat bu tutum fazla devam etmez, sanatın bilişsel değerini dikkate alan eserlerin sayısı giderek artar. "Dönemin aydınlarında, edebiyatın kitleler üzerindeki tesirini kullanmak suretiyle daha geniş çevrelere ulaşma eğilimi gözlenir. Zamanla sanatın, bireysel ya da seçkin bir haz aracı olarak görülmesi yerine, eğitici, ögretici ve anlaşılabilir de olabileceği fikri yerleşmeye başlar. Bu düşüncelerle Türk Edebiyatı'nda yeni bir dönem başlatmak isteyen aydınlar, birtakım yeni konu, tür ve biçimler denemek yoluna giderler. Başta Tercüman-ı Ahval (1860) gazetesi olmak üzere edebiyat, artı siyasal ve sosyal konuların işlendiği bir mecraya dönüşür. Yeni bir medeniyete evrilen Osmanl toplumuna, Arapça-Farsça eserler yerine Türkçe eserler ile seslenilir. Ancak bu dönemde, halk diliyle kaleme alınan söz konusu eserler, Batı Edebiyatı'nın tesirinde gelişir. Divan Edebiyatı'nı "Doğu” tesirinde kalmakla eleştiren aydınlar, bu sefer de "Batı" tesirinde kalırlar. Tanzimat dönemi, halka yönelişin ilk basamağını oluştururken halkın edebî zevkini yansitan verilere asıl yönelişler Millî Edebiyat dönemi ile başlar" (Akyüz, 2015: 19).

Osmanlı'da on dokuzuncu yüzyılın ikinci yarısında millî bir dilin oluşturulması ihtiyacı folklorun başlangıcını oluşturur. Folklor hareketleri ile milliyetçilik arasında sıkı bir ilişki mevcuttur. Osmanlı aydınları ve yazarları tarafından kullanılan dil, Arapça ile Farsçanın 
gramer kurallarından ve kelime hazinelerinden oluşmakta idi. Bu durum öyle bir seviyeye ulaşmışı ki Osmanlı halkı kanun dilini, resmi yazışma dilini ve edebiyat dilini anlamıyordu. Tanzimat yazarları, yabancı etkilerle kirletilmemiş, saf Türkçe olan halkın dilini kullanarak bir edebiyat yaratmak için halk bilimi ve halk edebiyatı ile ilgilendiler. Şinasi (1826-71) İstanbul'da oldukça basit bir dil kullanarak 1859'da bir tiyatro oyunu yazar, sonra da dört bin atasözünden oluşan bir derleme yayınlar. Ziya Paşa (1829-80) gerçek dilimiz ve edebiyatımızın halkın arasında yaşamakta olan dil olduğunu, milli şiirimiz ve nazımlarımızın hala ozanlar ve halk arasında canlı bulunduğunu ifade eder. Pek çok şair, romancı, oyun yazarı 1860 ile 1900 yılları arasındaki bu akımda yer aldılar. Hüseyin Rahmi (1864-1944) romanlarını popülerleştirmek için geleneksel hikâye anlatıcılarından yararlandı. 1839'da ilan edilen Tanzimat reformları Osmanlı edebiyatında fonksiyonel bir değişimi başlattı. Fransa başta olmak üzere, Batı ile sıkı ilişkiler içerisinde olan ve Avrupa'nın ekonomik, sosyal ve eğitim kurumlarını örnek alan yeni nesil Osmanlı yazarı, gelişmede edebiyatın önemli bir rol oynadığını fark ettiler. Onlar Türkiye'ye geri döndüler ve topluma bir mesaj aktaran dergileri, oyunları, kısa hikâyeleri ve romanları topluma tanıttılar. Yeni nesil yazarlar sosyal ve politik değişimleri gerçekleştirmek maksadıyla yeni türler kullandılar. Ancak buna rağmen insanları edebiyat yolu ile etkilemede sınırlı bir başarıya ulaştılar. Yazdıklarının dilini anlayabilen sadece küçük bir kitle vardı. Ahmet Mithat Efendi insanlara ahlakî değerleri öğretmek için kısa hikâyeler meydana getirdi. Abdülhak Hamid (1851-1937) oyunlarından birini atasözleri ve yerel ifadeler ile doldurdu. Yüzyılın başında milli duyguları ifade eden temaları işleyen ve halk şiirinin ölçü sistemini yoğun bir şekilde kullanan Mehmet Emin (1869-1944) millî şair unvanını kazandı (Başgöz, 2011: 1536).

Türk milliyetçiliğinin ortaya çıkışında, folklora karşı aydınların tutumlarındaki yeni dönem, belirleyici olmuştur. Avrupa'nın on dokuzuncu yüzyıl tarihini sallamış olan milliyetçilik, Türkiye'de I. Dünya Savaşı'na kadar önemli bir güç olamamıştır. Bu gecikmede, imparatorluğun heterojen yapısı önemli bir rol oynamıştır. Yunanlılar, Bulgarlar, Arnavutlar ve Araplar gibi azınlıklar arasında bir millî bilincin oluşması, İmparatorluğu yıkacak olan bağımsızlık hareketlerini hızlandırdı. Bu nedenle milliyetçiliğe kuvvetle karşı konuldu. Sultanlar ve münevverler sinıfi, İmparatorluğu bir millî Türk devleti haline getirme ve bir millî ruh yaratma imkânlarına sahip olmalarına karşın, kendilerini Müslüman ve Osmanlı olarak tanımladılar. Onlar, kendilerine Türkler denildiği zaman bir endişe hissettiler. Onlar için Türk, sadece eğitimsiz şehir halkını ve cahil köylüleri ifade etmekteydi (Başgöz, 2011: 1537). Avrupa'da İslam öncesi Türk tarihi ve dili hakkındaki çalışmalar, Osmanlı İmparatorluğu azınlıkları arasındaki milliyetçilik ve bağımsızlık hareketleri, 1908 reformunun başarısızlığı, Osmanlı birliği için yapılan son bir çağrı ve Alman emperyalizminin etkileri gibi bütün bu gelişmeler Türk milliyetçiliğinin ortaya çıkmasında katkıları olmuştur.

\section{Millî Edebiyat Dönemi Türkçülük/Milliyetçilik Hareketlerinin Kısa Bir Tarihçesi}

Millî Edebiyat dönemi, 1908 'de Meşrutiyet'in ilanı ile zemini oluşturulmuş, 1923'te Cumhuriyet'in ilanına kadar devam etmiştir. Türk milliyetçiliği bu dönemi şekillendiren temel düşünce akımıdır. Türkçülük siyasal ve sosyal alanda ulusallaşmayı hedef alarak, her türlü yabanc1 tesiri reddeder. Bu dönemde Ziya Gökalp, Türk milliyetçiliğinin itici gücü olarak görülür. Osmanlı aydınları da Balkan savaşları sonrasında azınlıkların ayaklanmalarına karşı bir tepki olarak Türk milliyetçiliğini benimsemişlerdir. Dönemin Türk milliyetçiliğinin öncüleri olarak Ali Suavi, Ahmet Vefik Paşa ve Süleyman Hüsnü gösterilebilir. Türk milliyetçiliği bu dönemde henüz doğuş sürecindedir. Türk milliyetçiliğinin çalışmaları, Türk tarihine 1şık tutmuş ve "kaba, cahil, göçebe" gibi tanımlamalara maruz kalan "Türk" kavramı, bir millet adı olarak tekrar anılmaya 
başlanmıştır.1911 yılında "Genç Kalemler" Dergisi etrafında toplanan aydınlar Türk milliyetçiliğinin edebî cephesini oluşturur. Türk millî edebiyatının kurulmasının gerekliliği ilk kez bu dergide dile getirilir. Bu hareketin amacı millî bir lisan, millî bir edebiyat vücuda getirmektir. Genç Kalemler, millî bir edebiyatın ancak millî bir dil ile mümkün olabileceğini savunurlar. Bunu gerçekleştirmek için Türkçenin sadeleştirilmesi çalışmalarına önem verirler ve yazı dilinde İstanbul Türkçesinin kullanılmasını önerirler. "Genç Kalemler" dergisi önceleri Ömer Seyfettin ile Ali Canip Yöntem'in çabalarıyla çıkar. Yenileşme ile ilgili görüş ve fikirleri topluma ulaştırmak için halk dilini bir araç olarak kullanır. Yazılarında halk lisanını kullanmalarına rağmen halkın edebî mahsullerine şekil ve içerik bakımından ilgi göstermezler. Bu durum, Ziya Gökalp ile birlikte farklı bir boyut kazanır. Ziya Gökalp, yeni ve modern bir cemiyetin felsefî ve sosyolojik boyutunu şekillendirir (Akyüz, 2015: 19-20).

Dârülfünûn'da Hikmet-i Tarih müderrisi Ahmet Vefik Paşa, ilmî Türkçülüğün önemli simalarından biridir. Ahmet Vefik Paşa Türkçülügün ilk esaslarını kurarken, Süleyman Paşa da Türkçülüğü askerî mekteplere sokmaya çalışır. Süleyman Paşa, mekteplerimizde okunacak Türkçülük ideolojisine uygun ilk tarih kitabını da kendisi hazırlar. Türkçülüğün ilk babaları Ahmet Vefik Paşa ile Süleyman Paşa'dır. Bu arada Rusya'da Mirza Fethali Ahundof ile Gaspıralı İsmail gibi iki büyük Türkçü yetişiyordu. Gaspıralı İsmail'ın “Dilde, fikirde ve işte birlik" şiarı tüm Türk dünyasında kabul görmüştür. Hüseyinzade Ali Bey, Rusya'dan İstanbul'a gelerek Tıbbiye'de Türkçülüğün esaslarını anlatmaya başlar. Yunan Harbi başladığı dönemde Mehmet Emin Bey,

\section{"Ben bir Türküm dinim cinsim uludur"}

mısrasıyla başlayan ünlü şiirini kaleme alır. Necip Asım Bey, Leon Cahun'un “Asya Tarihine Medhal" adlı kitabını birçok ilavelerle beraber Türklere ait kısmını Türkçeye nakleder. Bu kitap Türkçülüğe dair her tarafta büyük temayüller uyandırır. Ahmet Cevdet Bey, "İkdam” gazetesini Türkçülügün bir organı haline getirir. Bu arada Akçuralı Yusuf Bey ile Ferid Bey Türk birliğini savunan yazılar kaleme alırlar. Ahmet Hikmet Bey, Halide Edip, Hamdullah Suphi, Köprülüzade Fuad Türkçülük hareketinin önemli savunucularından bazılarıdır (Gökalp, 2007: 175-180).

"Türkçü olarak adlandırabileceğimiz grup, çalışmalarını Türk tarihi, mitolojisi ve kültürü alanında yoğunlaştırdılar” (Bayat, 2007: 28). Türk folklor ve tarihini bir bütünlük içinde öğrenmeye çalışan bilim adamlarından biri de Ziya Gökalp'tır. Gökalp yenileşme yanlısı diğer aydınların aksine sadece halk lisanına değil halk edebiyatı ve kültürüne de yönelir. $\mathrm{Bu}$ dönemde aydınlar, halkın anlamakta güçlük çektiği Arap ve Fars tesirinden uzak, sade Türkçe eserler vermeye çalışıllar. Ancak Batı tesirinde eserler vermelerinden dolayı yine toplumun asıl kaynaklarına uzak bir görünüm arz ederler. Gökalp, halktan uzaklaşan edebiyatın yönünü, orijinal bir karakter kazanabilmesi için tekrar halka döndürmek gerektiğini belirtir. Gökalp, Batı medeniyetinden de yararlanılabileceğini düşünür. Klasik Batı eserlerinin Türkçeye çevrilmesi gerektiğini vurgular. Edebiyatın millîleştirilmesinin yolu halk edebiyatından daha sonra Batı edebiyatından geçmektedir.

Toplumun temel gücü olan halkı ihmal etmeden bir yenilik planlanmak gereklidir. $\mathrm{Bu}$ bağlamda, dildeki Türkleşme ancak halkın konuştuğu sade dilin yazı dili haline getirilmesiyle gerçekleşecektir. Gökalp'a göre dil, milliyetçiliğin en önemli unsurlarından ve millî kimliğin temel dayanağıdır. Dil alanındaki egemenlik siyasal egemenliğin de ön şartıdır. Her alanda olduğu gibi dilde de Türkleşmek gerekir. Gökalp'a göre, asıl deha da halktadır. Bu düşünceden olmak üzere Gökalp, hemen hemen bütün şiirlerini - hatta mensur eserlerini- halk edebiyatı tesiriyle oluşturmuştur. Şiirlerinden Altın Destan, Ergenekon, Esnaf Destan1, Balkanlar Destanı, Kızıl Destan isimleri hem bir ideolojiye hem bir geleneğe 
işaret eder. Burada yer alan ideoloji Turan ideolojisidir. Gökalp, destan metinlerine millî meseleler ile ilgili görüşlerini yansıtmıştır. Destanların isminde dahi bu ideolojinin izlerini görülür. Türklerin tam bir devlet halinde olduğu, bütün hanların, İlhan yönetiminde birleştiği zamanı "Altın Devir" olarak adlandırır. Oğuz'un cihan hâkimiyeti mefkûresi Gökalp'ta "Turan" ideolojisine dönüşmüştür. Gökalp'ın, destan metinlerinde kullandığı "Turan", bir ütopya gibi onu sürekli heyecanlandıracak uzak bir mefkûredir ve gerçeklik sahasında yalnız "Türkiyecilik" vardır. Her ne kadar yeni olarak adlandırılsa da Gökalp, geçmişten bugüne kültürel aktarım yolu ile getirilen halkın edebî yaratmalarını, bu eski geleneği sürdürmeyi tercih eder. O, geleneksel olanı modern düzleme taşır. Şiirlerinde "Turan" idealini, topluma millî heyecan vermek amacıyla kullanan Gökalp, gerçeklik sahasında asıl ideolojisinin Türkiyecilik olduğunu vurgular. Türkçülügün en gür ve güçlü manzumelerini de bu amaçla yazar (Akyüz, 2015: 21-22).

Türk millî kültürü geçmişte Osmanlı devlet sisteminin dışında kalan etnik kimliklerle, dinlerle ve dillerle uyuşmazlık içerisindeydi. Türk millî kültürü düşüncesi artık zihinlerdeki bir hayal değildi. Türk millî kültürü düşüncesi, bir devlet politikası haline geldi. Yeni dönemin milliyetçi liderleri, İmparatorluğun politik yapısını değiştirmek, zihinlerde ve geleneklerde olduğu gibi eğitimde ve yasal sistemde de modernizasyonları gerçekleştirmek için 1923-30 arası boyunca kapsamlı bir reform programını uygulamaya başladılar. Saltanat ve halifelik kaldırıldı, yeni cumhuriyet ilan edildi. Avrupa'nın hukukî düzeni getirildi. Roma (Latin) alfabesi benimsenmiş ve Arap alfabesinin kullanımı yasaklanmıştır. Osmanlı entellektüelleri tarafindan yok sayılmış ve ihmal edilmiş olan ozanlar, kültür kahramanları haline geldi. Yeni liderleri, yeni değişimleri düşlediler. Türkleri bir arada tutmak için şerefli bir geçmişten gelen millî bir şuur duygusu olmadıkça başarılı olamayacaktı. Herkes tarafindan anlaşılabilecek olan ortak bir dilin vasıtasıyla yeni bir millî kültür meydana getirildi. Türk Dil Kurumu, yabancı sözcüklerden dili arındırmak göreviyle 1932 tarihinde kuruldu. Dünya medeniyetine Türklerin katkılarını keşfetmek, Asya dönemi boyunca Türklerin şerefli rollerini ortaya çıkarmak için Türk Tarih Kurumu kuruldu. Folklor alanındaki bilimsel aktiviteler, Fuad Köprülü'nün başkanlığı altında İstanbul Üniversitesinde 1924 yılında Türkoloji Enstitüsünün kurulmasıyla başladı. Türkiye Cumhuriyeti'nin ilk yirmi yılı boyunca Fuad Köprülü, folklor çalışmalarına diğer bütün bilim adamlarından daha çok katkıda bulunmuştur. Bir tarihçi olmasına rağmen o, Türk folkloru ile ilgili makaleler ve kitaplar yayınlamıştır. Ziya Gökalp'ın bir arkadaşı olarak Köprülü, milliyetçi prensiplerini takip etmiş ve onları edebiyat, tarih ve folklor çalışmalarına uygulamıştır. Çalışmalarının bilimsel liyakatinin yanında okuyucu onu ideolojik niteliğinden dolayı kolaylıkla tanıyacaktır (Başgöz, 2011: 1539-1540).

Gökalp'a kadar, halk bilimi malzemelerinin nasıl derleneceği ve derlenen malzemeyle ilgili nasıl bir çalışma yapılacağı konusu ile ilgili bir çalışma görülmemektedir. Gökalp, Türk halk bilimi çalışmalarının yöntemli olarak yapılması gerektiğine dikkat çeken ilk Türk aydınlarındandır. Çalışmalarıyla kendinden sonraki halk bilimi çalışmalarında bir öncü olmuştur. "Ziya Gökalp, Türk milliyetçisidir. Kurulacak yeni Türk devletinin sosyal ve kültürel yapısinin ancak halka doğru inerek ve halka ait malzemelerin derlenip değerlendirilmesiyle ortak bir kültüre ve geçmişe sahip olabileceğini öngörmüş ve bu düşünce temelinde folklor çalışmaların yürütmüsstür" (Nazlı Özyurt, 2008: 109). Ziya Gökalp'ın yaptığı çalışmalar Türk kültürü ve Türk halk bilimi çalışmalarında önemli bir yer tutmaktadır. Onun çalışmalarının etkileri ve yöntemleri günümüze kadar ulaşmış, onun izinde yürüyen birçok halk bilimci yetişmiştir. 


\section{Ziya Gökalp'ta Türkçülük Mefkûresi}

Öncelikle Türk kelimesinden ne anlaşılmalıdır? Gökalp'a göre Türk kimdir? Bu soruların cevabını bulmadan Türkçülügü anlamak mümkün olmayacaktır. Gökalp’a göre bazıları için yedi atası Türk olanlar, Türk'tür. Ancak kurtuluş yıllarına bakıldığında Arap mefkûresi için, Arnavut mefkûresi için çalışan Türkler vardı. Tunus'ta Turgut Reis'in torunları, Trablusgarp'ta Karamanlı ailesi Araplık için çalışıyordu. O halde yedi atası Türk olan tüm bunlara nasıl Türk diyebiliriz? Türlerden başka milletler için çalışan, asimile olan bu fertlerin hiçbirini Türk kabul edemeyiz. Bundan dolayı Türk olmak için sadece Türk kanı taşımak, Türk ırkından olmak yeterli değildir. Türk olmak için her şeyden önce Türk harsı ile terbiye görmek, Türk mefkûresi için çalışmak şarttır. Bu şartları taşımayanlara kanı ve ırkı Türk olsa bile Türk denemez. Kanca ve ırkça başka bir ırka mensup olan fertler, Türk harsı ile terbiye olmuş, Türk mefkûresi için çalışıyorlarsa onları da Türk kabul etmek iktiza eder. Türk halkına göre kendi diliyle konuşan, kendi dinine mensup her fert Türk'tü (Filizok, 2005: 161-162). Gökalp'a göre lisanıyla Türk'üm diyen ve samimî olarak kalbinde bu düşünceyi taşıyan her fert Türk'tür. Bu özelliklere sahip fertlerin Türklüklerinden asla şüpheye düşülmemelidir. Türk olmak için, Türk doğmak yeterli değildir. Türk gibi duymak, Türk gibi hissetmek, Türk gibi irade edip Türk gibi çalışmak lazımdır.

Ziya Gökalp'ın fikir dünyası Türkçülük temeline oturur. Önceleri Osmanlıcılıktan, İslamcılığa kadar değişen görüşlerin sahibi olmuşsa da, bunların etkisi çok çabuk geçmiş ve sonunda Türkçülükte karar kılmıştır. İttihat ve terakki Partisi (ITP)'nin Gökalp üzerinde büyük etkisi görülür. $\mathrm{O}$, bir taraftan buradaki aydınların fikirlerinden etkilenirken diğer taraftan bunları derinden etkileyecek yeni fikirler ortaya atar. Gökalp, İTP'nin büyük kurultayı için 1909 yılında Selanik'e gider. $\mathrm{Bu}$ dönem, fikirlerinin bir kısmının sorgulanmasını ve yeni açılımları beraberinde getirir. Gökalp, burada ulusalcı eğilimlerle karşılaşır. Bu karşılaşma önceki fikirlerinde bir takım değişimler meydana getirir. Böylelikle Gökalp, yeni çözüm yollarını sunma gereğini duyar. Bu dönemde yoğun olarak Durkheim, Comte gibi batılı düşünürlerin fikirlerinden etkilenir (Acet, 2014: 68-69). İTP döneminin "Türkleşmek, İslamlaşmak, Muasırlaşmak" eserindeki düşüncelere bağl1 görünen Gökalp, cumhuriyet döneminde de "Türkçülüğ̈̈n Esasları"na bağlı kalır. Bu kitap, Türk ulusunun var olması yolunda neler yapılabileceğini ortaya koymak amacıyla kaleme alınmıştır. Türkçülüğün Esasları, değişen koşulların bir sonucudur. Koşullar zorunlu olarak fikirleri de beraberinde değiştirmiştir. Savaş sona ermiş, imparatorluk dağılmıştır. Bu koşullar Gökalp'ın, görüşlerini yeni koşullara uydurma çabasını beraberinde getirmiştir. "Milliyetçiliğin hızl yayılışı karşısında direnmenin boş olduğunu düşünen Ziya Gökalp, Osmanlı devletinin kurtuluş yolu olarak Türkleşme akımını görmektedir. Zaten ona göre bütün Batı devletleri milliyetçi bir yapıya büründükleri için bu kadar gelişebilmişler, çağdaşlaşmaya kendisine hedef edinen Osmanlı da milliyetçi bir yapıya bürünmeliydi. Osmanl devletinin bugüne kadar ekonomi ve askeri yönden düstüğü durumu da çoğu zaman milliyetçi bir yapının olmamasına bağlayarak kurtuluşun milliyetçilikte olduğunu belirtir" (Acet, 2014: 99). Gökalp'a Türkçülük fikrini aş1layan ilk kişiler, ilk Türkçü olarak kabul edilen Osmanlı Paşaları, Avrupalıların başını çektiği şarkiyatçılar ile Rusya'daki ve Osmanlıdaki Türkçülerdir. Gökalp, milliyet fikrinin savunulmasıyla Osmanlının ayakta kalabileceğini savunur. Milliyet fikrinden yoksun olan halklar bencil, menfaatperest, ümitsiz ve korkaktırlar. Bu yüzden kurtuluşun ve bütün gelişmelerin ana sebebi milliyetçilik fikridir.

"Ziya Gökalp (1876-1924), Türk milliyetçiliğinin babast, o tarihte Türk milliyetçiliğinin prensiplerini formüle etti. Onun mesajı uygun-doğru bir zamanda belirdi ve dağılan imparatorluğun kalıntılarından bir milli bilinç yaratmaya çalışan Türk entellektüellerini bir araya getiren bir çığlık oldu. Gökalp milli tarihte, edebiyatta ve dilde Türk milli kimliği için 
araştırmalar yaptı. Onun sisteminde tarih, edebiyat ve dil; Türklerin kirlenmemiş doğal kültürü ile Osmanlı kültürünün yer değiştirmesinde ve Türk insanını (milli bilinç etrafinda) birleştirme hususunda ana kaynaklar olarak görülür. Doğru milli kültüre ulaşabilmek için Osmanlı'nın her şeyi çürütülmeliydi. Osmanlı kültürü ve müesseseleri Gökalp'in ideolojisinde önemli derecede olumsuz bir rol (günah keçisi rolü) oynamıştır” (Başgöz, 2011: 1538).

Ziya Gökalp, "folklore" kavramını Türk diline "halkiyat" (halkın bilimi) olarak çevirdi, 1922'ye kadar da bu şekilde kullandı, bu tarihten sonra "halkiyat" kavramının uluslararası arenada kullanılan şekli olan "folklore" kavramını kullanmaya başladı. 1912 yılının başlarından halk hikâyeleri derledi. Çocuklar arasında milliyetçi duyguları yaygın hale getirmek için bu halk hikâyelerini şiirleştirdi ve onları ilham kaynakları olarak kullandı. Ayrıca millî bir destan yaratmak için Dede Korkut'un bazı hikâyelerini şiirselleştirdi. Daha sonra hikâyeler kaleme alıp yayınlamaya başladı. Gökalp milliyetçilik hedefine uygun hale getirmek için, hikâyelerinde kullandığı dili, tarzı ve karakterlerin isimlerini de değiştirdi. Gökalp, ideolojisini hayata geçirmek için Türk folklorunu büyük bir eğitici aygit haline getirdi. Şiir ya da düz yazı olarak yayınladığı çalışmalarında, hikâyelerinin coğrafî sahasını, ihmal edilmiş olan Asya'yı, Türklerin anavatanı haline getirdi. Kahramanların isimlerini Türk tarihinin efsanevî ve gerçekçi kahramanlarının isimleri ile değiştirdi. Örneğin, masalının kadın kahramanı Ay Hanım, Türk'tür. Yıldız, Müslüman'dır ve Üvey Ana ise İngiliz'dir.

"Türk düsünce tarihinin kuşkusuz en önemli ismi Ziya Gökalp'tır. Görüşleri derleme, yüzeysel, dağınık diye eleştirilse bile bugüne değin Türk akademik hayatında da serbest düsünce ortamlarında da onun kadar kapsamll, derinlikli, sistematik ve etkili bir Türk düşünürü yetişmemiştir. Eğer etkisine bakılacak olursa, anılan eleştirilerin bir bakıma yersiz olduğu da söylenebilir. Bir imparatorluk tarih sahnesinden çekilip ulus-devlet kurulurken çeşitli düşünce akımlarının, beklentilerin ve uğraşların sınır boylarında yetişen Gökalp, Türklerin son yüz elli yılında en önemli tartışma alanlarına yüreklice girmiş, çeşitti kuramlar ortaya atmış, tartışmış, akım yaratmış bir Türk düşünürüdür" (Öztürk, 2011: 320).

Ziya Gökalp “Arslan Basat” adlı şiirinde Zaloğlu Rüstem'e açık göndergede bulunur. Zaloğlu Rüstem, İranlı ünlü kahramandır. Şehnâme'de adından övgüyle bahsedilir. Eski şiirimizde kahramanlık, yenilmezlik ve gücün sembolü olarak sıç̧a kullanılır. Sicistan ve Seyistan hükümdarı Zal'ın oğludur. "Ziya Gökalp, Türk kahramanı olan Basat'ın gücünü anlatmak için Iran'in efsanevî kahramanı Rüstem'le karşı karşıya getirir. Basat, Rüstem'i esir almış, onu tahtından indirmiştir. Ziya Gökalp'ın buradaki amacı öncüsü olduğu Türkçülük düşüncesini metninde işleyerek, Türk'ün gücünü dünyaya göstermektir"' (Bars, 2013: 237). Arslan Basat, şiiri Ziya Gökalp tarafından 1917 yılında yazılmıştır. Şiirin son bölümü daha sonradan, Kurtuluş Savașı'ndan sonra, șiire eklenmiștir. Ziya Gökalp yaşadığı dönemin sosyal ve siyasî konularını şiirine almış, fikirlerini şiirin muhtevasına yerleştirmiştir. Anlamsal yönden şiirin arasına Türkçülük ideolojisini sokar. Ziya Gökalp, Türkiye Cumhuriyetinin kuruluş döneminin Türkçülük düşüncesinin en önemli teorisyenlerinden biridir. Ziya Gökalp, Türk fikir hayatında adından çokça söz ettiren bir düşünce adamıdır. Birçok eserinde Türkçülük düşüncesini işler. "Ziya Gökalp, şiirin temeline fikrî muhtevayl yerleştirir" (Aktaş, 1996: 159).

Ziya Gökalp, Türkiye'de Türk folklor ve etnografyasını Türk kültür sahasındaki çalışmalarında ilmî materyalleri ve esas kaynakları ilk kullanan Türk bilginidir. Gökalp, bütün dünya Türklerinin bir kül halinde olan folklorunu, yazılı kaynaklarından ziyade sözlü kaynaklarını da kullanmıştır. "Ziya Gökalp'ın Türk ilim ve irfanına, Türklük fikir ve mefkûresine yaptığı hizmetler öyle büyüktür ki, bizim burada işaret ettiğimiz noktalar onlar 
küçümsemeye vesile olamaz. Bilâkis kendisinin bütün hayatın vakfettiği yüce gaye hesabına değerlendirilmek gerekir. Türk ilminin, Türklük hakikatinin ve haklarının kendi milletimize ve dünya medeniyetine tanitılması için Gökalp’ın sarfettiği gayretler bu gibi tamamlayıcı incelemelerle o yüksek gayeye daha fazla yaklaşmamızı sağllyacaktır” (İnan, 1998: 234). Gökalp'ın fikirleri, özellikle yeni bir devletin kuruluşunda, Atatürk üzerinde milliyetçilik, din ve batılılaşma konularında tesirli olmuştur. Türkiye Cumhuriyeti'nin kuruluşunu takip eden yıllarda Gökalp'ın başlıca fikirleri tatbikat sahasına konmuştur. Gökalp' ın fikirleri Türkiye Cumhuriyeti'ne şekil ve istikamet vermiştir. Atatürk inkılaplarının temelinde Gökalp'ın düşünceleri vardır. Atatürk, Gökalp'ı fikirlerinin babası olarak görür (Eren, 1972: 173).

"Kızllelma", Türkler arasında cihan hâkimiyetinin sembolüdür. Kızılelma Türklerin yasadıkları bölgeye göre daha batıda, ulaşılması gereken bir yerdir. Kızılelma, hâkimiyetin veya fethedilmek üzere seçilmiş yerin sembolüdür. Kızılelma motifi Türklerde çok eski inançlara ve töreye dayanır. Barlık suyu boyunca oturan Oğuzları, buradan hep batıya doğru yürüten güç Kızılelma olmuştur. Kızılelma çok güçlü bir fetih idealinin sembolü olmuştur. Ergenekon Destanı'nda Ergenekon'dan çıkma ve eski yurda yeniden sahip olma idealidir. Ulaşılması gereken, ülkeleri ele geçirmek için fetihleri amaç hâline getiren bir semboldür (Özdemir, 2008: 504). Türkler hangi yöne giderlerse gitsinler elde etmek istedikleri zafere, Kızılelma adını vermişlerdir. Osmanlılar, fethetmek istedikleri yerlerde bir Kızılelma'nın varlığına inanmış ve bunu ele geçirmek için çabalamışlardır. Kızılelma'nın arzulanan bir emel, gaye ve somut hedef hâline gelişi daha çok Osmanlılarda görülür. Türk'ün ortak bilinçaltında yaşayan bu ideal Osmanlılar zamanında yazılı kaynaklara da geçmiştir. "Kızllelma ideali, 20. yüzyıl basından itibaren gelişen Türkçülük akımı ve geliştirilmek istenen millî mefkûreyle tekrar gündeme gelmiş ve bu görüşleri savunanlar için motive edici bir güç olmuştur. Bunun edebiyata yansımaları ise Ziya Gökalp'te ve Ömer Seyfettin'de görülür” (Özdemir, 2008: 505). Gökalp Kızıl Elma'yı 1913 yılında Türk Yurdu dergisinde yayımlar. Eserini eski mesneviler seklinde ve ideolojik yönü ağır basan bir tarzda kaleme alır. Kızıl Elma şiiri ideolojik içerikli bir şiirdir. Kızıl Elma, bu şiirde çöken bir devletin yerine, bütün Türklerin bir araya gelerek kuracakları Turan devletidir. İkinci Meşrutiyet'ten sonra özellikle Ziya Gökalp'ın çalışmalarıyla, imparatorluğun Türk unsuruna milliyetçilik fikrini aşılamak, onları geniş bir Türklük dünyasından haberdar etmek çabaları, ana vatan kavramından uzaklaştırıyordu. Kızılelma motifi, Türk mitolojisinde ulaşılması gereken hedeftir (Özdemir, 2008: 508).

Devlet kendisine ait bir hükümete kavuştuğunda, bir araziye, bir ahaliye sahip olduğunda zümre meydana gelir. Devletler kavmî, sultanî ve millî olmak üzere üçe ayrilabilir. Günümüzde büyük devletler millî devlet olma yolundadır. Millet, ümmet ya da saltanat içinde uzun süre kalmasından dolayı şahsiyetini kaybeden bir toplumun tekrar şahsiyet kazanmasıyla ortaya çıkan kavimdir. Kavimler, kavmî bir dine, kavmî bir devlete, kavmî bir medeniyete ulaşınca, varacakları en üst noktaya varmış olacaklardır. Kavimler tarih içinde ortak bir dine, ortak bir devlete, ortak bir medeniyete dahil olmuşlar ve zamanla şahsiyetlerini kaybetmişlerdir. Bugün bu üç müşterek hayattan kendi şahsiyetini kurtarabilenler millet olmuştur. Millet halinde yeniden doğan, doğduğu zaman o artık eski kavim değildir (Filizok, 2005: 93-94).

\section{Ziya Gökalp'ta Türkçülüğün Esasları}

Gökalp'a göre kültürün en önemli üç unsuru bulunmaktadır: dil, din ve tarih. Bundan yola çıkan Gökalp milleti aynı dili konuşan, aynı dine iman eden ve ortak bir geçmişi olan insan topluluğu olarak tanımlar. Ona göre bir ülkede farklı kavimlerden insanlar ortak bir kültür etrafında birleşerek bir millet oluşturabilirler. "Osmanlı Imparatorluğu'nun dă̆llma 
döneminde hayatını geçiren Gökalp de, Osmanlı İmparatorluğu için çıkış yolunun Türk milliyetçiliğinden geçtiğine inanmaktadır. Türk milletinin ayakta kalabilmesi için izlenmesi gereken yol milliyetçiliktir. Aksi takdirde Türk milleti tarihten silinip gitmek zorunda kalacaktır. Türk milliyetçiliğinin ideologu olarak kabul edilen Gökalp, ayrica yeni kurulan Türkiye Cumhuriyeti'ne de görüşleriyle ilham vermiş, hatta Türk kelimesinin ön plana çıkmasında öncü rol oynamıştır” (Duran, 2011: 154-155). Türkçülük, Türk milletini her alanda yükseltmek, ileriye taşımaktır. Gökalp'ın Türkçülük anlayışında Türk milletini diğer milletlerden üstün görme yoktur. Gökalp'a göre tüm ırklar eşit oldukları gibi tüm milletler de eşittir. Millî dayanışmanın kuvvetlenmesi sonrasında ise milli kültür yükseltilmelidir.

Gökalp, şiirlerinde genelde Türklükten, Türk olmaktan gurur duyulmasından söz eder. Tanrı, Türk'ü yüce yaratmıştır. $O$, Türklük soyundan gelmiştir, Türk unvanı her unvandan üstündür. Türk milleti, bölünmez bir bütündür. Millet uğrunda can verilir. "Gökalp'a göre cemiyetin ü̧̈ ülküsü vardır. Bunların üçüncüsü millettir. Milleti de oluşturan kadın erkek iki vicdandır. Milli medeniyetin beşiği millettir ve bu medeniyetin de milletten ögrenilmesi gerekir. Doğru sanat, doğru din, doğru ahlak halkın içindedir. Buradan da anliyoruz ki Gökalp, insanın sahip olduğu milli manevi değerlerin milletten ögrenilmesi görüşündedir" (Yılmaz, 2012: 60). O, millet sevgisini milliyetçilikle bağdaştırmaktadır. Batı'dan Doğu'dan gelen değişikliklere uymak yerine, onların bize uymalarını sağlamamız gerekmektedir.

Gökalp, Doğu medeniyeti ile Batı medeniyetinin uzlaştırılamayacağını düşünür. Söz konusu iki medeniyet arasında karşıtlık olması nedeniyle bir millet her iki medeniyeti bünyesinde barındıramaz. Bir insan iki dine bağlı olamayacağı gibi, bir millet de iki medeniyete katılamaz. Bu nedenle, Türkler, ya bütünüyle Doğu medeniyetinin içinde kalmak ya da büsbütün Batı medeniyetine katılmak zorundadır "Gökalp, alınmasını gerekli gördüğü öğeleri medeniyet kavramının içine dahil eder. Bu bağlamda, medeniyeti pozitif bilimlerle teknoloji pratiklerinin toplamı olarak niteleyen Gökalp, milletler arasında ortak olması gereken söz konusu iki öğe çerçevesinde başvurulacak yerin Avrupa olduğunu belirtir. Çünkü, Gökalp'e göre, içinde bulunulan yüzyılın medeniyeti Avrupa medeniyetidir. Dolayıslyla, Gökalp, toplumsal yaşamın bütün boyutları itibariyle bir Batılılaşmadan söz etmemektedir" (Oğuz, 2012: 147).

\subsection{Türkçülük nedir?}

Gökalp’a göre Türkçülük Türk milletini yükseltmek demektir. Türkçülüğün mahiyetini anlamak için öncelikle millet adı verilen zümrenin bilinmesi gereklidir. Irkî Türkçülere göre millet, ırk demektir. Her hayvan nevi, teşrihi vasıfları itibariyle bazı tiplere ayrılmışlardır. Mesela at türünün Arap 1rkı, İngiliz 1rkı gibi. Irkın içtimaî hasletlerle hiçbir münasebeti yoktur. Kavmî Türkçüler, milleti kavim zümresiyle karıştırırlar. Kavim aynı ana-babadan türemiş, içine yabancı karışmamış kandaş demektir. Günümüzde kavmî saffet hiçbir cemiyette bulunmamaktadır. Coğrafî Türkçülere göre millet aynı ülkede oturan ahalilerin toplamıdır. Onlara göre bir İran milleti, bir İsviçre milleti vardır. Halbuki İran'da Farsî, Kürt, Türk'ten ibaret üç millet vardır. İsviçre'de Alman, Fransız ve İtalyanlardan ibaret yine üç millet vardır. Bu muhtelif cemiyetlerin lisanları ve harsları birbirinden ayrı olduğu için bunlar birer millet değildir. Osmanlılara göre millet, Osmanlı İmparatorluğunda bulunan bütün tebaadır. Bu halitada müstakil harslara sahip çok millet olduğu için burada da büyük bir hata vardır. İslam ittihadçılarına göre millet, bütün Müslümanların hepsidir. Aynı dinde bulunan insanların mecmuuna ümmet denir. $\mathrm{O}$ halde Müslümanların mecmuu bir ümmettir. Son olarak fertçilere göre millet, her adamın kendisini mensup addettiği herhangi bir cemiyettir. Fertlerde böyle bir hürriyet ve istiklal yoktur. Bir ferdin istediği zaman mahiyetini değiştirebilmesi kendi elinde değildir. $\mathrm{O}$ halde millet nedir: Millet lisanca, dince, 
ahlâkça ve bediiyatça müşterek olan, yani aynı terbiyeyi almış fertlerden mürekkep bulunan bir zümredir (Gökalp, 2007: 181-185).

\subsection{Türkçülük ve Turancılık}

Gökalp'a göre Türkçülük ile Turancılık birbirlerinden tamamen farklı iki kavramdır. Türk bir milletin adıdır. Millet kendisine mahsus bir harsa malik zümredir. Bugün harsça birleşmesi kolay olan Türkler, Oğuz Türkleridir. Türkiye, Azerbaycan, İran ve Harezm ülkelerinin Türkmenleri, Oğuz uruğuna mensupturlar. Türkçülükteki yakın mefkûremiz "Oğuz İttihadı"dır. Bu dört ülkenin mecmuuna "Oğuzistan" adını verebiliriz. Türkçülüğün uzak mefkûresi ise "Turan"dır. Turan, "Turlar" yani Türkler demektir. Turan kelimesi Türkler demek olduğu için hususî olarak Türkleri ihtiva eden camiavî bir isimdir. Turan kelimesi bütün Türk şubelerini içine alır. O halde Turan, bütün eski akrabaları kavmî bir camia halinde birleştiren müşterek bir unvandır. Turan, Oğuzları, Tatarları, Kırgızları, Özbekleri, Yakutları lisanda, edebiyatta, harsta birleştirmektir. Yüz milyon Türk'ün (1923) bir millet halinde birleşmesi, Türkçüler için en kuvvetli bir vecit kaynă̆ıdır. Turan bugün için uzak bir hayal gibi görülebilir. Dün Türkler için hayalî bir mefkûre olan millî devlet bugün bir gerçektir. Bugün gerçekte Türkiyecilik vardır. Kızıl Elma, hayal sahasındadır (Gökalp, 2007: 186-189).

\subsection{Türkçülüğün Programı}

Türkçülük sekiz mebhastan (fasıldan) oluşmaktadır:

a. Lisanî Türkçülük: Türkiye'nin millî lisanı İstanbul Türkçesi'dir. İstanbul'da iki Türkçe vardır. Birincisi konuşulup yazılmayan İstanbul Lehçesi, diğer, yazılıp da konuşulmayan Osmanlı Lisanı'dır. Bu ikisini birleştirmek zorundayız. Konuşma dilini yazarak yazı dili haline getirmeliyiz. Osmanlı edebiyatının yanında, halk diliyle yazılmış bir Türk edebiyatı yedi asırdan beri vardır. Osmanlı lisanını hiç yokmuş gibi bir yere atarak, halk edebiyatına temel vazifesini gören Türk dilini aynıyla millî lisan kabul etmek yeterlidir (Gökalp, 2007: 237-238).

b. Bediî Türkçülük: Eski Türklerde bediî zevk çok yüksekti. Selçuk Türklerinin, Harezm Türklerinin, İlhanlıların, Osmanlıların vb. Mısır'da, Suriye'de, Anadolu'da, İran'da, Hint'te vs. yaptırdıkları camiler, saraylar, türbeler, köprüler, çeşmeler dünyanın en güzel eserlerini oluşturur. Türkmen kızının bir harika nevinden olarak yaptıkları nakışlarla süslü nefis halılar vücuda getirebilmesi ancak tabiî bir sanat zevkine sahip olmasındandır. Türk masallarıyla halk şiirlerinin güzelliği Türklerin bediiyat sahasında büyük bir kabiliyete sahip olduğunu gösterir (Gökalp, 2007: 256).

c. Ahlâkî Türkçülük: Büyük milletlerden her biri özel bir alanda diğer milletlerden öndedir. Eski Yunanlılar bediiyatta, Romalılar hukukta, İsrail ve Araplar dilde, Fransızlar edebiyatta Türkler de ahlâkta birinciliği kazanmışlardır. Türk tarihi baştan başa ahlâkî faziletlerin meşheridir. Türklerin mağlup olan milletlere ve onların millî ve dinî varlıklarına izin vermesi, bunlara müdahalede bulunmaması her türlü takdirin fevkindedir (Gökalp, 2007: 266).

d. Hukukî Türkçülük: Bunun gayesi Türkiye'de asrî bir hukuk meydana getirebilmektir. $\mathrm{Bu}$ asrın milletleri arasına geçebilmenin en esaslı şartı millî hukukun bütün şubelerini teokrasi ve klerikalizm bakiyelerinden kurtarmaktır. Asrî devletlerde kanun yapmak ve memleketi idare etmek salahiyeti doğrudan millete aittir. Milletin bütün fertleri tamamıla birbirine müsavidir. Hukukî Türkçülügün gayesi asrî bir devlet oluşturmak ve meslekî velayetleri mütehassısların salahiyetine bırakmaktır. Diğer bir gayesi de asrî aile vücuda 
getirmektir. Kanunlarımızda hürriyete, eşitliğe ve adalete aykırı ne kadar kural, teokrasiye ait ne kadar iz varsa hepsine son verilmelidir (Gökalp, 2007: 283).

e. Dinî Türkçülük: Dinî Türkçülük din kitaplarının ve hutbelerle vaazların Türkçe olması demektir. Bir millet dinî kitaplarını okuyup anlamadığı sürece dininin hakiki mahiyetini anlayamaz. Hatiplerin, vaizlerin ne söylediklerini anlamadıkları sürece ibadetlerden zevk alamaz. İbadetten alınacak feyiz okunacak duaların anlaşılmasına bağlıdır. Bütün duaların ve hutbelerin Türkçe okunması lazım gelir (Gökalp, 2007: 284).

f. İktisadî Türkçülük: Türkler en eski zamanlarda göçebe idiler. Bu zamanda Türk iktisadı çobanlık esasına müstenitti. O zamanlarda Türklerin bütün servetleri koyun, keçi, at, deve, öküz gibi hayvanlardan ve yedikleri süt, yoğurt, peynir, tereyağı gibi hayvanî mahsullerden ibaretti. Eski Türkler ticarete de yabancı değillerdi. Büyük ticaret yolları bazı dönemler tamamen Türklerin ellerindeydi. Türkler mazide olduğu gibi bu iktisadî refaha istikbalde de mazhar olmalıdır. Her türlü sefalete nihayet vererek umumun refahını temin için ne lazımsa yapılmalıdır. Türklerin bundan sonraki iktisadî mefkûresi memleketi büyük sanayiye mazhar etmektir (Gökalp, 2007: 285-287).

g. Siyasî Türkçülük: Türkçülük siyasî bir firka değildir. İlmî, felsefî, bediî bir mekteptir. Türkçülük büsbütün siyasî mefkûrelere bigâne kalamaz. Türk harsı sair mefkûrelerle birlikte siyasî mefkûrelere de maliktir. Türkçülük asrî bir cereyandır ve asrî mahiyette bulunan cereyanlarla ve mefkûrelerle itilâf edebilir. Halkçılıkla Türkçülük daima el ele verecek, yeni mefkûreler âlemine beraber yürüyeceklerdir. Her Türkçü siyaset sahnesinde halkçı kalacaktır. Her halkçı da hars sahasında Türkçü olacaktır. Siyasette mesleğimiz halkçılık, harsta mesleğimiz Türkçülüktür (Gökalp, 2007: 288-289).

h. Felsefî Türkçülük: İlim, objektif ve müspet olduğu için evrenseldir. İlimde Türkçülük olamaz. İlmin ispat ettiği hakikatleri felsefe nefyedemez. Felsefenin objektif ve sübjektif olmak üzere iki cephesi vardır. Felsefe, ilim gibi evrensel olmak zorunda değildir. Her milletin kendisine göre bir felsefesi vardır. Bundan dolayı ahlâkta, bediiyatta, iktisatta olduğu gibi felsefede de Türkçülük olabilir. Halk felsefesi nokta-i nazarından Türkler, bütün milletlerden daha yüksektedirler. İki ordu veya iki milletin savaşmasında, birisinin galip diğerinin mağlup olmasının en başlıca nedeni iki tarafın felsefeleridir. Türk felsefesi Asya, Afrika, Avrupa milletlerine ait felsefelerden daha yüksektir. Felsefî Türkçülük, Türk halkındaki millî felsefeyi arayıp meydana çıkarmaktır (Gökalp, 2007: 290-291).

\section{Sonuç}

Gökalp tarafından kurgulanan romantik-milliyetçilik akımı, onların öğrencileri arasında hâlâ egemen bir akımdır. Onlar Anadolu Türk kültürüne Orta Asya Türk kültürünün doğrudan kalıntıları olarak bakarlar. Antik dönem Anadolu, Orta Doğu ve Balkan kültürlerinin sebep olduğu yabancı etkiler en asgari seviyededir ve yok sayılmalıdır. Bu düşünce çeşitli üniversitelerde ağırlıklı olarak desteklenmektedir ve Milli Eğitim Bakanlığının da desteğine sahiptir. Türk milliyetçiliğii, İmparatorluğun yıkılmasıyla meydana gelen kültürel boşluğu doldurmak için Türk folklorundan taze, saf ve millî bir kaynak buldu. Onların inandıkları bu yeni kaynak, yeni Türkiye Cumhuriyetini bir araya getirmek için kuvvetli bir güç sağladı ve milletin modernleşmesini kolaylaştırdı.

Gökalp tarafından teorisi ortaya atılan Türk milliyetçiliği ile daha önceki yüzyıllarda yaşanan din, mezhep ve irk ayrımlarından kaynaklanan savaşlara son verilmiştir. Türk milliyetçiliği ile siyasal, kültürel ve ülkü birliğine dayanan birlikteliğin temeli atılmıştır. Türk milliyetçiliği, barışçı bir hedefi öngördüğünden saldırgan ve yayılmacı amaçları reddetmiş, daha gerçekçi bir politikaya dayandırılmıştır. Milliyetçiliğin getirdiği siyasî, sosyal ve 
hukuksal eşitlik, Türk toplumunu oluşturan bireylere güven kazandırmıştır. Kendi kimlikleri ile her alanda atılım yapmaları ve gelişme hamleleri için heyecan, cesaret ve özgüven sağlamıştır. Türkiye Cumhuriyeti'ni yüksek idealine ulaşmasında ülkeyi yöneten, söz sahibi olacak kişi, kurum ve siyasî oluşumlara kendi milletine güvenmesini sağlamıştır. Dün olduğu gibi bugün de milliyetçilik ulusların tarihsel kimliklerini destekleyen ve birada yaşama iradesini güçlendiren en önemli ideolojik akımlardan biridir. Milliyetçilik uygulama alanı en etkin olan düşünsel hareketlerin başında gelmektedir.

Gökalp ırka dayalı bir millet tanımı yapmaz. Milletler çeşitli şekillerde birbirleriyle karışmışlardır, bu nedenle de ırkın, milletin oluşumu üzerinde herhangi bir etkisi yoktur. Irk, hayvanlarda aranması gereken bir vasıftır ve kesinlikle insanlarda 1rkî özellikleri aramak doğru değildir. Gökalp, Türk milleti içerisinde olan Arnavut veya Arap kökenli olan Türkleri örnek göstermiştir Bu kişiler, Türklük için hizmet etmiş ve her türlü kederde mutlulukta Türk milleti ile aynı duyguları paylaşmışlardır. Bu nedenle bu kişilerin Türk olmadıklarını iddia etmek doğru değildir.

Türk tefekkürü tarihinde Ziya Gökalp, muhiti üzerinde en çok tesir uyandırmış düşünürlerden biridir. Bir taraftan Türkçülügün tekâmülü yolunda çalışan Gökalp, bir taraftan da Türk içtimaiyatı ve Türk edebiyatı alanlarında devrinin âlim ve sanatkârlarına yol göstermiştir. Türkiye'de muasır içtimaiyat ilmini o kurmuştur. Millî edebiyat hareketlerinin geri dönülmez bir cereyan hâlini almasında en büyük katkıyı o sağlamıştır. 


\section{KAYNAKÇA}

ACET, Mehmet Tahir. (2014). Ziya Gökalp'ta Din ve Milliyetçilik. Yüksek Lisans Tezi. Dicle Üniversitesi Sosyal Bilimler Enstitüsü Felsefe Ve Din Bilimleri Ana Bilim Dalı Din Sosyolojisi Bilim Dalı.

AKTAŞ, Şerif. (1996). Türk Şiiri ve Antolojisi 1. Ankara: Akçă̆ Yayınları.

AKYÜZ, Çiğdem. (2015). Yeni Lisan, Eski Tarz: Ziya Gökalp'in Koşma ve Destanları. Turkish Studies International Periodical For The Languages, Literature And History Of Turkish Or Turkic, 10/4, 17-26.

BARS, Mehmet Emin. (2013). Ziya Gökalp'ın “Arslan Basat” Şiirine Metinlerarası Bir Bakış. Uluslararası Türkçe Edebiyat Kültür Eğitim Dergisi, 2/1, 229-242.

BAŞGÖZ, İlhan. (2011). Türkiye'de Folklor Çalışmaları ve Milliyetçilik (çev. Serdar Uğurlu). Turkish Studies- International Periodical For The Languages, Literature And History Of Turkish Or Turkic, 6/3, 1535-1547.

BAYAT, Fuzuli. (2007). Mitolojiye Giriş. İstanbul: Ötüken Neşriyat.

DİNÇ, Sait. Atatürkçü Düşünce Sistemine Göre Milliyetçilik İlkesi. http://turkoloji.cu.edu.tr/ATATURK/arastirmalar/sait_dinc_ataturkcu_dusunce_sistem i_milliyetcilik_ilkesi.pdf.

DURAN, Murat. (2011). Türk Milliyetçiliğinin Üç İdeoloğu: İsmail Gaspıralı, Yusuf Akçura ve Ziya Gökalp. Yüksek Lisans Tezi. Gazi Üniversitesi Sosyal Bilimler Enstitüsü Kamu Yönetimi Ana Bilim Dalı Siyaset ve Sosyal Bilimler Bilim Dalı.

EREN, Hasan. (1972). Atatürk ve Ziya Gökalp. Türk Dili Aylık Dil ve Edebiyat DergisiDosya: Atatürk 1881-1938, 254, 172-177.

FíLiZOK, Rıza. (2005). Ziya Gökalp. Ankara: Akçağ Yayınları.

GÖKALP, Ziya. (2007). Türkçülüğün Esasları (haz. Mustafa Koç). Bütün Eserleri BirKitaplar. (yay. haz. M. Sabri Boz). İstanbul: Yapı Kredi Yayınları. 165-298.

İNAN, Abdülkadir. (1998). Z. Gökalp ve Türk Folkloru. Makaleler ve İncelemeler II. Ankara: Türk Tarih Kurumu Basımevi. 232-234.

NAZLI ÖZYURT, Ayşenur. (2008). Ziya Gökalp'ın Halk Bilimi Çalışmalarındaki Yeri. Yüksek Lisans Tezi. Gazi Üniversitesi Sosyal Bilimler Enstitüsü Türk Halk Bilimi Ana Bilim Dalı.

OĞUZ, Gökhan. (2012). Sosyolojik Yaklaşımlı Türk Milliyetçiliğinde Türk Modernleşmesi: Ziya Gökalp, Mümtaz Turhan, Erol Güngör, Yılmaz Özakpınar. Doktora Tezi. Marmara Üniversitesi Sosyal Bilimler Enstitüsü Kamu Yönetimi Ana Bilim Dalı Siyaset ve Sosyal Bilimler Bilim Dalı.

ÖNERTOY, Olcay. (1965). Halide Edip'in Yeni Turan'1 ve Ziya Gökalp. Türkoloji Dergisi II, I. Ankara Üniversitesi Yayınları, 251-258.

ÖZDEMIR, Fatih. (2008). Kızıl Elma’yı Arayan Üç Yazar: Ömer Seyfettin, Ziya Gökalp, Ragıp Şevki Yeşim. Turkish Studies International Periodical For The Languages, Literature And History Of Turkish Or Turkic,3/5, 503-515.

ÖZTÜRK, Nurettin. (2011). Ziya Gökalp’ın “İslamiyet ve Asrî Medeniyet I-II” Adlı Makalesi Üzerinde Bir inceleme ve Metin. TÜBAR-XXIX, 319-340. 
TANSEL, Fevziye Abdullah. (1989). Ziya Gökalp Külliyatı-1 Şiirler ve Halk Masalları. Ankara: Türk Tarih Kurumu Basımevi.

YILMAZ, Esra. (2012). Ziya Gökalp'ın Şiirlerinin Değerler Eğitimi Açısından İncelenmesi. Yüksek Lisans Tezi. Karadeniz Teknik Üniversitesi Eğitim Bilimleri Enstitüsü Türkçe Eğitimi Anabilim Dalı. 